\title{
Peacebuilding as Practice: Discourses from Post-Conflict Tajikistan
}

\author{
JOHN HEATHERSHAW
}

International Peacekeeping, vol.14, no.2, June 2007, [post-print version]

\begin{abstract}
Peacebuilding is a contested concept which gains meaning as it is practised. While academic and policy-relevant elaboration of the concept is of interest to international experts, interpretations of peacebuilding in the Central Asian arena may depart immensely from those envisaged within the Western-dominated 'international community'. This article opens up the dimensions and contingent possibilities of 'peacebuilding' through an investigation of two alternative approaches found in the context of Tajikistan. It makes the critique that peacebuilding represents one contextually-grounded basic discourse. In the case of Central Asia, and in particular postconflict Tajikistan, at least two other basic discourses have been adopted by parties to the post-Soviet setting: elite mirostroitelstvo (Russian: peacebuilding) and popular tinji (Tajik: wellness/peacefulness). Based largely on fieldwork conducted in Tajikistan between 2003 and 2005, the argument here is that none of these three discourses are merely artificial or cynical constructs but that each has a certain symbolic and normative value. Consequently, a singular definition of Tajik 'peacebuilding' proves elusive as practices adapt to the relationships between multiple discourses and identities in context. The paper concludes that 'peacebuilding' is a complex and 'intersubjective' process of change entailing the legitimation of new relationships of power.
\end{abstract}

\section{Introduction}

Defining 'peacebuilding' is an immense challenge. Indeed the question of what is 'peacebuilding', is not separable from the question of how peacebuilding is practised. ${ }^{1}$ It is a 'travelling concept' and finds new meanings wherever it visits, in Central Asia as much as elsewhere. The immediate implication of this statement is that the search for a core definition of peacebuilding may well be futile, and is at least of lesser importance than how 'peacebuilding' is variously and discursively practised within the region. The question is of particular importance when one considers that the transformation of these 
practices is the very object of the idea itself. The case of post-conflict Tajikistan indicates that three distinct 'basic discourses, ${ }^{2}$ of peace are present and interdependent: international, elite and popular. If international interventions in the name of furthering individual rights, safety and welfare in Central Asia are unable to engage with and transform state and societal practices they will remain 'thin simplifications' of reality in the region. ${ }^{3}$ The interventions of the international community must be aware of specific local understandings and practise constructive relationships with them in order to understand what may reasonably be attained in terms of peacebuilding.

A re-consideration is required. One approach is to rationalise the concept down to a narrower basis which can then be widely accepted in the 'international community'; some attempt has been made in this direction. ${ }^{4}$ This approach becomes problematic, however, when singular rational designs meet diverse human interpretations and practices. A more fruitful alternative to rationalization is to broaden our understanding by considering how it has been practised within its various contexts. Thus, any comprehensive reading of 'peacebuilding' in a particular context requires a consideration of other 'selves': ${ }^{5}$ the different discourses in play and the various voices at work in popular and elite contexts. Here the distinctions in academic and policy-orientated texts between peacebuilding, human security and human development may be less relevant than the distinctions between international, regional and local contexts. It is this spatial differentiation of 'peacebuilding' among three basic discourses within a given field that is the focus here.

Based on fieldwork conducted between 2003 and 2005, the paper considers the various discourses of 'peacebuilding' in the Tajik case. In section one, the paper looks at peacebuilding, with respect to the case of Tajikistan, showing how it performs neo-liberal norms of post-conflict democratization for an international audience, despite actual practices which depart substantially from these precepts. Section two provides a thumbnail sketch of the discourse of mirostroitelstvo represented by the notions of 'authority' and 'stability'. Section three examines the popular discourse of tinji as a discourse of harmony which depoliticizes the Tajik social setting and seeks to avoid or accommodate conflict. The paper concludes with some cautionary words for practitioners of peacebuilding. 


\section{Peacebuilding in Tajikistan}

While hardly counting as a paradigmatic case, Tajikistan offers challenging insights on international practice. This short section offers a brief introduction to the context of the peacebuilding - the dominant discourse of international interventions.

\section{War and peace in Tajikistan}

In 1992, following the break-up of the Soviet Union, Tajikistan experienced several months of intense fighting and descended into civil war. Although the most widespread fighting had ended by 1993, a peace agreement was not signed until 1997, and significant political violence continued sporadically until 2001. The war and its consequences have dominated Tajikistan's short history. The 'Kulyobization' of Tajikistan, ${ }^{6}$ where cadres from the southern region of Kulyob (who had provided the troops which brought progovernment forces back to power in late-1992) came to hold most of the key positions in government, despite the power-sharing mechanism of the General Agreement. This trend was apparently confirmed by Emomali Rahmonov's re-election in 1999's fraudulent presidential elections. However, Tajikistan has avoided fragmentation along regional lines and descent into further conflict. Government, opposition, and international actors have often worked together successfully to re-establish security in the country and to begin rehabilitating the economy. A 2003 referendum on constitutional changes, despite being conducted without international monitoring and with protests from much of the opposition, passed off peacefully and cleared the way for President Rahmonov to remain in power for two further terms. In 2005, international observers concluded that Tajikistan's elections failed to meet international standards and included 'large-scale irregularities' amid a near consensus among the international community in Tajikistan that these elections were worse than the previous ones of $2000 .^{7}$ As such, Tajikistan presents a singular case of transition from war to 'peace' and begs the question, upon what is Tajikistan's 'peace' based?

A 2004 report by the International Crisis Group (ICG) argued that the international community looked on while the Tajik government accumulated power in its hands and marginalized political foes. 'Quiet diplomacy has its merits,' they argued, 'but ignoring the problems of Tajikistan's political development threatens to undermine the very stability that the international community is dedicated to protecting., ${ }^{8}$ The ICG 
seemed to suggest that a conservative or gradualist, as opposed to a more energetically liberalizing, process of conflict resolution had allowed a legitimate settlement to change into an increasingly illegitimate and resolutely anti-democratic institution-building process. This criticism goes to the heart of the dilemmas faced in peacebuilding by international actors intervening with liberalizing mandates. The idea that a functioning liberal-democratic system can be transplanted into a context lacking certain institutional and ideological antecedents may be a misnomer, in Tajikistan or elsewhere. However, peacebuilding remains the dominant prism through which the successes and failures of the Tajik 'peace' are interpreted.

\section{Peacebuilding discourse}

A large part of both official and academic international analyses of Tajikistan's politics and society per se, assumes that democratisation and post-conflict peacebuilding are inseparable processes. Under the liberal imperatives of the international community it offers the promise of democratization as in Betram's understanding of UN peacebuilding: 'Designed to address the root causes of conflict, it entails building the political conditions for a sustainable democratic peace, generally in countries long divided by social strife, rather than keeping or enforcing peace between hostile states and armed parties. ${ }^{9}$

This reflects a discourse of peacebuilding which takes on the burden of the 'mission civiliatrice' as has been well-documented by Paris among others. ${ }^{10}$ It is, he argues, guided by the doctrine of liberal internationalism while 'transplanting western models of social, political, and economic organisation into war-shattered states. ${ }^{11}$ This is manifested in the international political discourse of peacebuilding - where it is presented in absolute terms: 'there is no alternative'. Thus, the concept must be recognized as expressive and normative, in other words 'a way to stand for and promote certain ideals.' 12

Indeed, the UN approach of 'post-conflict peacebuilding' emerged amid a reawakening of liberal internationalist ideals in the 'international community' in the aftermath of the cold war. However, the earlier concept of democratization can be considered its discursive cousin, sharing peacebuilding's epistemological and ontological roots, and being hugely influential in its own right in directing international engagement with post-Soviet and post-colonial states. This link between peacebuilding and 
democratisation (as well as development) is explicit in the policy literature. ${ }^{13}$ BoutrosGhali noted in 1993:

Without peace there can be no development and there can be no democracy. Without development, the basis for democracy will be lacking and societies will tend to fall into conflict. And without democracy, no sustainable development will occur; without such development, peace cannot long be maintained. ${ }^{14}$

Much academic writing in conflict studies reflects the general tenor of this approach and has served to encourage the broadening of its application across dimensions (for example, from the security sector to psycho-social wellbeing), time (from pre- to post-conflict), and space (for example, 'the community'). Reducing long-term social and political change to a series of problems that can be solved, peacebuilding is a discourse that simulates a universal transition to democracy.

Importantly, the temporal broadening of peacebuilding to make it something which takes place over 'generations' creates greater confusion regarding the measurement of its success. This is functional for the discourse of peacebuilding as achievements can be claimed despite the lack of verifiable progress, and disappointment of apparent lack of progress in the near-term can be offset. A good example of this is the Human Security Report of 2005 which argues for the success of international peace operations. 'Not one of the peacebuilding and conflict prevention programs on its own,' the authors contend, 'had much of an impact on global security in this period [since the end of the Cold War]. Taken together, however, their effect has been profound. ${ }^{, 15}$ One could argue that this is only via ideology of the purest kind that the sum of these rather unpromising parts somehow mystically equates to an overall reduction in the incidence of conflict. However, an ideologically-informed notion of progress is intrinsic to the peacebuilding discourse. Such thinking reflects a dichotomy where the peril of further conflict can only be avoided through the promise of democratization. In this sense peacebuilding presents a win/lose game with political leaders and their citizens (somehow together) standing at a junction with a choice of two diverging pathways, one of which must ultimately be chosen. 
Public international discourse with respect to Tajikistan consciously reflects peace-building's positive dimension. The UN Tajikistan Office of Peace-building (UNTOP) was established, according to the Security Council, 'in order to consolidate peace and promote democracy. ${ }^{, 16}$ The UN Secretary-General's representative in Tajikistan, Vladimir Sotirov, who heads the UNTOP, remarked in 2002 that, 'there is a wish and will in the leadership of the country to introduce democratic principles of governance and development in the society, in an effort to create a vibrant civil society.' Furthermore he noted:

I am encouraged by the democratic developments so far in this country. I believe if it continues to move in the same direction in the future, it will quickly develop into a pluralistic democracy. However, a lot of difficulties have to be overcome, especially in the field of further separation of powers, mass media, promotion and the protection of human rights, thereby encouraging civil society, reforming power structures, and continuing with a spirit of tolerance and dialogue in the society. ${ }^{17}$

Such optimism is not confined to international organisations but is represented by those expressing the broader identity of the international community. In March 2004, the US Ambassador to Tajikistan, Richard Hoagland, remarked that he was 'optimistic about democracy in Tajikistan' and that 'in the first instance, this is because the government has chosen a democratic path. ${ }^{18}$ While these fine words may be dismissed by some as rhetoric, underlying such statements are peacebuilding's axioms regarding the sustainable post-conflict state. Furthermore, the blurred boundary between policy and academic analysts means that the promise of peacebuilding is a key element of many analyses of the Tajik war and 'peace" ${ }^{19}$. It has, moreover, provoked considerable international intiatives in terms of peacebuilding's priorities including decentralization and selfgovernment in local communities, the development of a political party system and the carrying-out of free and fair elections, and the reform of the security sector. ${ }^{20}$ 


\section{Peacebuilding versus 'peace': an assessment}

It is possible and potentially enlightening to conduct an institutionalist analysis of the practices (institutions) of Tajik peacebuilding. In the limited context of this article, a general overview of peacebuilding's institutional impact will be attempted on its own terms. From its ideologically-informed precepts, the discourse often creates a 'dual subject' in conflict - the state and its citizens. Literature on peacebuilding often distinguishes between bottom-up and top-down dynamics concerning, respectively, the concepts of 'civil society' and 'governance'. The latter has more recently been elaborated discursively as 'state-building', most often in American debate in the context of the troubled interventions in Afghanistan and Iraq. ${ }^{21}$ In this context, state-building and peacebuilding are often labelled as 'nation-building. ${ }^{22}$

Quantitative growth in non-governmental organizations (NGOs) does not equal qualitative growth in civil society and in itself may indicate little more than the latest fad of Western donors. Is there a link between the growth in NGOs and Tajikistan's 'peace', or is this relationship merely illusory? What role do these organisations actually play in society? Abbas notes that the discourse of civil society in Tajikistan is largely conducted and imposed by elites, with little consideration of 'the personal and societal experiences of post-communist citizens and how those experiences have shaped citizens' approaches to society and politics today'. ${ }^{23}$ The author's own research indicated reluctance on the part of the vast majority of NGOs to become involved in activities that might be deemed 'too political' ${ }^{24}$ In the area of small arms and light weapons, for example, some civil society representatives in Dushanbe feel that even beginning programmes on such issues might be seen as 'oppositional' by the government. ${ }^{25}$ This picture of deference and accommodation is repeated to a greater or lesser extent across Central Asia. Many NGOs are concerned with educational and women's issues which are considered less political. They are often small, poor and badly managed, having 'very limited' or 'inadequate' impact on conflict resolution. ${ }^{26}$ Furthermore, as Liu and Megoran inter alia have argued, 'civil society' in Central Asia expresses local and international power relations. ${ }^{27}$ The 'DONGO' (Donor-organized Non-Governmental Organization) model, Liu notes, is fundamentally disempowering to micro-level reform and may indeed be subverted by local clients. Therefore, 'attempts to encourage "grassroots" initiatives may end up reinforcing such illiberal institutions as patriarchy and clientelism. ${ }^{28}$ 
The role of the political elite in the top-down processes of governance and statebuilding departs markedly from peacebuilding's norms. While the government has consciously incorporated the language of democracy into its legal framework and public pronouncements, it is unconstrained by either democratic mechanisms or a pluralistic political culture. President Rahmonov and his supporters dominate parliament and all the institutions of state. Saodat Olimova and Anthony Bowyer, draw parallels with other countries in Central Asia. The Tajik polity is characterized by a 'hyper-personification of power' - the accumulation of power in the hands of an elite who are in some sense accountable horizontally but ignore 'the interests of the electorate by maintaining conditions of continual crisis.' The functioning of the system is accordingly 'susceptible to clan influence and corruption' and the rule of law is 'weak'. They cite the following democratic deficits:

- Hypertrophy of the authority of the executive branch

- Accelerating growth of bureaucracy

- Weak role of parliament in the decision-making process

- Insubstantial judicial supervision

- Extreme fragmentation of the political, business, bureaucratic and military elites along ethno-regional lines

- Overlapping of state and private interests

- Corruption in all sectors and on all levels of government. ${ }^{29}$

Given these conditions, John Schoberlein, argues that there is an observable movement against democratization: 'as Rahmonov consolidates his power, he and his supporters are working to reduce pluralism. ${ }^{30}$ Despite this, scope for compromise exists within the system and it seems inappropriate to label Tajikistan as a fully authoritarian system. Shirin Akiner argues, 'the current trend is towards the semi-institutionalisation of power struggles among different individuals and/or interest groups, economic, regional, and political. 31

It is the underlying argument of this article that the success of Tajikistan in avoiding further war is more than a historical anomaly or a temporary reprieve, and that the lack of progress in democratization is more than a matter of impatience with an inevitably long-term process. Tajikistan as a particular case of peacebuilding refuses to 
abide by its peril/promise dichotomy. Moreover, its unresolved status represents a paradox of peacebuilding. ${ }^{32}$ How, it must be asked, did peacebuilding get it so wrong? Why are its assumptions about the nature of conflict resolution so inappropriate to the Post-Soviet Central Asian context? The above analysis indicates that in institutional terms, Tajik peacebuilding functions quite differently from the model exhorted in the discourse of peacebuilding. However, I contend that an institutionalist analysis in and of itself is incomplete without a grasp of the normative and symbolic dimensions of practice. The following section looks at a regionally-specific alternative approach to peacebuilding.

\section{Mirostroitelstvo among Central Asian elites: peace enforcement}

Among most Tajiks the post-conflict period is understood in strikingly different terms than found in the portrayals of the international community. At regional and local levels dominant voices are found to deny the existence of conflict and legitimise patriarchy and clientelism. In my research I have come to define and explore two inter-related but clearly distinct discourses of Tajik 'peacebuilding' which are essential to the maintenance of of Tajikistan's 'peace'. The first, which I have called mirostroitelstvo, represents the approach of national and regional (elite) representatives towards peace and security not just in Tajikistan, but prevalent across Central Asia ${ }^{33}$.

\section{Post-soviet mirostroitelsvo: origins and context}

It is widely acknowledged that Russian peacekeeping challenges conventional notions of impartial, third-party peacekeeping, limited in both scope and duration. The interpretation and contextualisation of peacebuilding in the Russian speaking areas of the former Soviet Union are indebted to the norms and symbols of post-Soviet space. The translation of UN Security Council decisions and international doctrines of peacebuilding and peacekeeping means that more than the original English is lost in translation. While Russian doctrine borrows much from UN language, its practical interpretation both in Moscow and on the ground bears little resemblance to liberal ideals of the 'international community'. Indeed the Russian term 'mirotvorchestvo', literally meaning 'peace-making' or 'peacecreating', used to translate the English 'peacekeeping', implies a much more hands-on approach than that authorized by most UN peacekeeping mandates. This is less a 
technical matter of translation than an issue of a 'travelling concept' which takes on a new meaning in a different political context. Thus, unlike liberal notions of peacebuilding via democratization and socio-economic development, it has come to represent a 'neosoviet' and distinctly authoritarian approach to conflict resolution.

According to Trevor Waters, in Moldova, for example, Russian peacekeeping represented 'an instrument of unilateral interference in a separatist conflict to further Moscow's neo-imperialist interests'. Furthermore, Waters argues that Russian peacekeeping 'allowed Transdniestrian separatists to build up armed forces and consolidate illegal state structures', despite overwhelming international opposition. ${ }^{34}$ In Georgia, the behaviour of individual ex-Soviet garrisons was crucial to the course of the conflict, noting an instinctive hostility towards nationalist forces by Russian commanders which led to significant support for separatist forces, particularly in Abkhazia. ${ }^{35}$ Many analyses, such as that of John MacKinlay and Evgenii Sharov ${ }^{36}$, are careful to make a clear distinction between Moscow's strategic aims, which went through considerable upheaval during the 1990s, and the local tactics of Russian forces, noting that much depended on the orientation of commanding officers. The influence of mirotvorchestvo as an instrument for retaining Russian hegemony in the near abroad, alongside consistent hostility towards nationalists among Russian commanders, played a significant role in the post-Soviet state formation of Georgia, Moldova and Tajikistan.

In the former Soviet Union, discourses of peacekeeping (mirotvorchestvo) and peacebuilding (mirostroitelstvo or mirostroyeniye) among national and regional elites are joined by a common understanding of 'peace'. This is perhaps best illustrated by the case of Tajikistan where in the early 1990s the oppositional nationalist-Islamic forces were successfully marginalized as Moscow sought a loyalist to preside over a Russian protectorate state. Smith-Serrano argues correctly that the peacekeeping mission itself has become much less significant than the 'border control mission' along Tajikistan's southern frontier with Afghanistan. ${ }^{37}$ It is under Russian protection that Rahmonov has been able to defy many UN and OSCE initiatives towards democratization, expand his personal power and re-establish a secular, authoritarian regime in Dushanbe. Dov Lynch provides an excellent analysis of how the inchoate relationship between Moscow and its commanders nevertheless served Russia's neo-imperial ambitions. ${ }^{38}$ The character of Russian peacekeeping and peacebuilding raises important questions about the ideological 
context which bonds Moscow to its post-Soviet allies in the Commonwealth of Independent States (CIS). In this sense, mirostroitelstvo can be understood not just as an institutionalized approach to 'peacebuilding' but as a regionalized discourse of state elites which represents certain norms about the nature of international relations and conflict resolution that are altogether more 'statist' and authoritarian.

\section{Mirostroitelstvo as peace enforcement}

Central Asia was largely bypassed by Gorbachev's new thinking and four out of five first secretaries of the Central Asian republics supported the August 1991 coup against Gorbachev. Perestroika and glasnost had little impact on power structures within Tajikistan although via Moscow they did facilitate the relative pluralism of the late-1980s and early-1990s which preceded the civil war. Today in Tajikistan, elites often explain a heavy-handed approach to political parties or the media with reference to the civil war and the dangers of pluralism. Furthermore it is often said that it is 'our mentality' (nash mentalitet), with reference to the former Soviet Union, that makes such 'Western-style' pluralism inappropriate. My own experience of conducting numerous interviews with heads of local government and state officials over the last two years suggests that two key concepts - 'stability' (stabilnost) and 'authority' (avtoritet) - are important in this selfassigned mentality of political elites in Central Asia. Within the scope of this paper, only a brief look at the ideologically-informed usage of these two terms is possible. They serve to reproduce an imagined 'Central Asian' regional community. ${ }^{39}$

First, the notion of 'stability' is typically used to explain the priority of economic development over democratization. As the head of an 'opposition' party, which is largely loyal to the Rahmonov administration, remarked, 'democracy doesn't give us bread. ${ }^{40}$ Here democratization becomes a gradual process which must happen in our own gradualist way, and can only happen after a significant level of economic development has been achieved. Second, the term avtoritet is often used to signify a person who has authority among his peers and is able to have political impact. The following quote is illustrative. In discussing the strength of the President's political party, one of its leaders explained: 
The position of the party became so strong when Emomali Sharipovich Rahmonov - a person who has colossal avtoritet! - became our Chairman. Why? First, he promised the Nation that he would end the war. Second, he at once said that all political migrants and forced evacuees should return to the homeland. Third, he said, that he'd resolve the problem of hunger. That's how the avtoritet of this person came about! Our party did not increase his avtoritet. He gave this avtoritet to the party. [Pause] I myself am a historian. For example, in some countries... In Egypt. Anwar Sadat and those who were before him - they were given avtoritet by the party. But in Tajikistan it was the opposite. Emomali Rahmonov gave the party his personal avtoritet, and we used it and raised the avtoritet of our party. Nowadays we do everything so that this avtoritet is maintained and increased. ${ }^{41}$

Such a view is almost always held by a state official or someone tied into official structures. In contrast, civil society organizations emphasize their non-political nature even when they are being funded by international organizations to support programmes which are apparently political such as voter education, gender issues or conflict resolution. The concept of avtoritet helps inscribe the dominance of an elite network which is apart from and untouchable by a donor-funded civil society sector. Together, the notions of avtoritet and stabilnost provide a normative basis for the processes of peace enforcement that are prevalent among post-Soviet political elites. As is well-evinced by the case of Russian involvement in Chechnya, if eradication fails to eliminate opposition to the elite, containment may be used until eradication is finally 'successful'.

In the field of international relations two extreme positions can be taken with regard to such contextually-located discourses. Many political realists dismiss the cultural context, making these 'beliefs' merely cynical justifications for those in power. On the other hand 'orientalist' readings - from both 'inside' and 'outside' - reify such contextual phenomena as 'tradition', 'culture' or 'mentality'. This article opposes both these polar positions which effectively serve as straw men for more serious discussions of the nature of culture and identity in peacebuilding. Here, opposing discourses reflect and reproduce 'selves' of political and cultural identity. ${ }^{42}$ The belief in stabilnost and avtoritet is not simply the strategy of power hungry elites; it has a cultural resonance which to a certain 
degree is shared by many citizens in the region, in particular those who hold positions within state structures, including so-called reformers. Moreover, like the internationally more prominent concept of peacebuilding, it is not simply analytic but also expressive and performative. As such it can both shape the assessments of 'interest' by decisionmakers and it can legitimate hard-line actions, both for an inner circle of decision-makers and a wider public.

\section{Tinji in Tajikistan's communities: conflict avoidance and accommodation}

While mirostroitelstvo is self-consciously political, and sets strikingly different terms of rule than the discourse of peacebuilding, the second discourse is self-consciously 'antipolitical'. In Tajiki there are numerous words for peace. However, the commonly-used notion of tinji (wellness/peacefulness) perhaps best conveys the feelings of many who shy away from social and, especially, political conflict. The voices of the Tajik powerless consciously reflect their disinterest towards, and weakness vis-à-vis, the politically powerful. Ironically, this gives the discourse of tinji enormous political impact as an essential element in the maintenance of Tajikistan's 'peace'. The symbiosis between mirostroitelstvo and tinji is based on a common understanding of the political - which justifies the dominant relationship of state over society. The following analysis of tinji is based on research conducted for the International NGO Mercy Corps with communitybased organizations (the Community Initiative Group [CIG]), citizens, community leaders and representatives of local government in five communities in Sughd oblast of Tajikistan. $^{43}$

\section{Denying the existence of conflict: a harmony ideology}

Conflict largely remains unacknowledged or weakly acknowledged in Tajik communities. Tension (Russian: naprazheniye) or disquiet (Russian: bezspokoystvo) is attributed to brief arguments caused by the lack of resources. Less common is the acknowledgement of tension with local government or with other villages (where the dispute is again over resources). When asked to identify threats there was significant agreement between community leaders and members - with both identifying the lack of work opportunities and the consequent affects of unemployment and labour migration as 
the most significant threat to peace (Tajiki: tinji; Russian: spokoystvo). Table 1 illustrates the answers of sixty respondents to the question: 'What is the greatest threat to peace in the village?' Strictly political or security threats were not cited at all.

\section{TABLE 1 ABOUT HERE}

Table 1: Perceived Threats

What is the greatest threat to peace in the village?

\begin{tabular}{|l|c|c|c|c|c|}
\hline Community & $\begin{array}{c}\text { Unemployment } \\
\text { \& labour } \\
\text { migration }\end{array}$ & $\begin{array}{c}\text { Lack of water } \\
\text { and other } \\
\text { resources }\end{array}$ & $\begin{array}{c}\text { Illiteracyl } \\
\text { alcoholism/ } \\
\text { drug addiction }\end{array}$ & None & Grand Total \\
\hline Koshonar & 7 & 2 & & 3 & 12 \\
\hline Margedar & 11 & 1 & & & 12 \\
\hline Novabad & 6 & & 6 & 4 & 12 \\
\hline Navbuned & 2 & 6 & & 1 & 12 \\
\hline Tojikokjar & 27 & 9 & 7 & 17 & 60 \\
\hline Grand Total & & & & & 12 \\
\hline
\end{tabular}

To probe this perception further it is interesting to look at the perceptions of community and personal livelihood. Community leaders give the impression that while circumstances remain difficult, the material conditions of the community have improved over recent years. The results from villagers are somewhat more mixed, with women far more likely to acknowledge poverty than men. ${ }^{44}$ However, attempts to measure personal views of conflict and livelihood were often thwarted by an interpretation of 'you' as necessarily meaning 'the community' - part of a broader public discourse of community togetherness. Elsewhere, this has been called a 'harmony ideology'. ${ }^{45}$ Under such a worldview, community members refuse to acknowledge any disagreements or even any personal opinions for fear of breaking from the group. The harmony ideology of the Peaceful Communities Initiative (PCI) communities was particularly strongly represented by the CIGs.

\section{Unity and cohesion}

While a harmony ideology indicates a denial of conflict, in Tajikistan it is accompanied by affirmations of community unity. Perhaps, the most revealing demonstration of this 
worldview in my research was provided during the bilingual Russian/Tajik StrengthsWeaknesses-Opportunities-Threats (SWOT) analysis conducted with the CIG in Novabad. When asked to identify the strengths and weaknesses of the village, and the opportunities and threats that they face, the CIG identified the aspects detailed in Table 2. In this depiction the central concepts are unity/cohesion and harmony. Strengths and opportunities relate to the achievement of unity, weaknesses and threats relate to insufficient unity. While a harmony ideology might be seen as an avoidance or even denial of the actual existence of conflict, it is important to recognise that such discourse can be, to a certain extent, productive. This is not to say that it ends perceptions of inequality, or stifles all tensions and arguments but it can to some extent act as to control what is and is not acceptable in public space, and hence serve as a self-fulfilling prophecy.

\section{[TABLE 2 ABOUT HERE]}

Table 2. SWOT Analysis Novabad

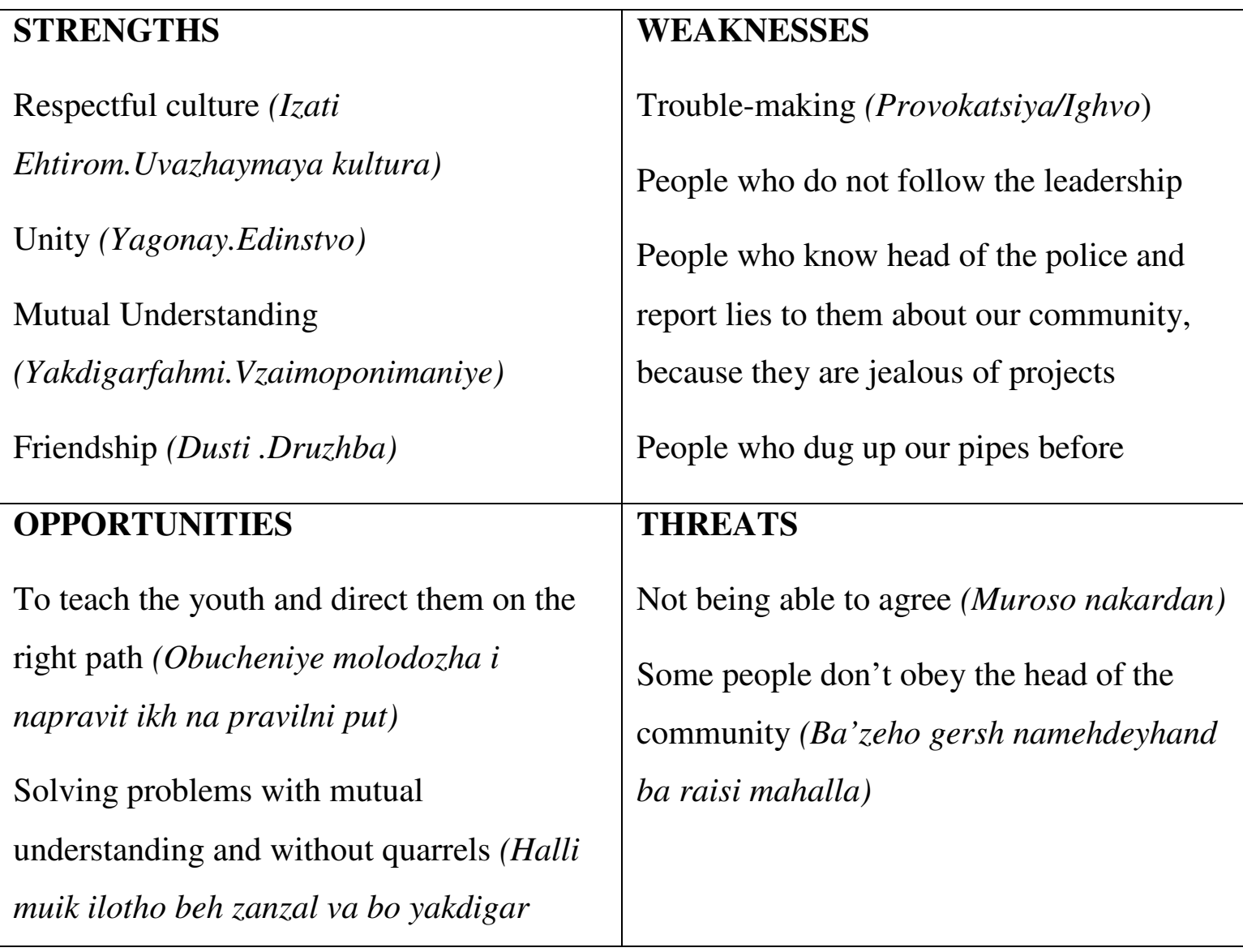


orahmi)

The overall theme of unity carries over into how PCI communities are managed. The two most common words attributed to community problem-solving are 'cohesion' (Russian: splochonost) and 'activeness' (Russian: aktivnost). Often they are used together to imply that an active community is one that coheres, and a coherent community is one that is active. When asked, 'do people listen to your voice?' the head of Koshenar community committee (mahalla) noted, 'Yes, of course. The village represents one family, from one root (koren).' The community leader (raisi mahalla) in Margedar, who served forty-five years as a brigadir from the first day the community was opened until 1997, described, 'Because I worked with them from the first day. All men and women grew up under my eyes. The people trust me and would not be able to deceive me.' In Tajik villages the community is denoted as the mahalla which can be both used to refer to the community as a whole and, sometimes in the same breath, the head (rais) of the community. ${ }^{46}$ In addition the title aksakal (literally 'grey beard') is used for older men in the community who have special status as decision-makers and conflict-enders. In any of these variants a group of, most commonly, older men meet in the teahouse (choihonawhich also functioned as the mosque and general community centre) on a daily basis and discuss the life of the village. The young and, especially, women are rarely present at these times. While in other parts of Central Asia attempts have been made to formalize the mahalla committee or equivalent body by making it an organ of local government (Uzbekistan) or advisory council (Kyrgyzstan), in Tajikistan the mahalla has remained entirely informal notwithstanding the attempts of international organizations to formalize it through the establishment of community-based organizations.

Given the nature of this 'unity', community members cite numerous examples of the mobilization of people for collective voluntary labour (khashar) prior to the involvement of the PCI. 'Mobilization' here is understood as calling on people to provide free labour for a community goal which has been decided by the Rais and other 'respected' community members or even local government. Informal ties are important and there are real processes of participation in place for those of a certain standing. While decision-making may not be exclusively top-down, it is clear that certain sections of the community may be listened to more than others. A majority of men, in particular older 
men, cite that they feel listened to, while just two out of fifteen younger women felt that their voice was heard in the community. However, for many people there is little sense that this is a problem. The CIG leader in the village of Koshonor was quite open that "the voice of women has no kind of meaning'. The women in his group vociferously agreed. ${ }^{47}$

\section{Anti-politics}

A reluctance to acknowledge conflict or dispute (raznogalsiye) and the emphasis on the value of unity, despite evidence of inequality, is accompanied by a further aspect of Tajiki tinji: a strong aversion to the political sphere. The CIG in Margedar provided a particularly strong example of this. 'In our village', one man noted, 'peace (spokoystvo) is one of our strengths.' Another man added, as if to support him, 'there are no tensions, no kind of political parties.' At this point he was somewhat chided by fellow group members for mentioning politics. The Margedar community leader (raisi mahalla) in a later interview agreed that there was no political tension. However, contrary to the CIG he acknowledged, 'there are political parties but there are no contentious [sporni] questions between them.' ${ }^{48}$ More generally, citizens strongly express deference to and respect for the state - both the idea of it and its representatives. Such examples offer glimpses of the retreat from the political which has taken place in Tajik society since the numerous popular political movements of perestroika, prior to the civil war. The association of plural and competitive politics with war is extremely strong. Accordingly, the political becomes a sphere left for one united group, the 'authoritative' elite. This discursive practice of tinji is accordingly emboldened in interaction with the elites of mirostroitelstvo.

The question poised by peacebuilders is to what extent such attitudes, that I have presented as a discourse of tinji, are fragile pretensions which barely cover up a considerable anger toward the ruling powers. Is the expression of harmony, unity and anti-politics disingenuous? Is the discourse merely a 'thin simplification' of reality? ${ }^{49}$ It is the author's judgment that hatred of conflict, along with compromising and moderate attitudes of individuals, is sincere and reflects other aspects of the social structure and cultural values of Tajik society. Such depoliticized representations of the world can be productive in Tajikistan. They are undoubtedly politically beneficial to ruling elites who act to reconfirm such beliefs in their everyday practices of governance. However, they 
also reflect a genuinely held disbelief in, and retreat from, the value of politics on the part of the vast majority of citizens. This is often characterized as 'war weariness'. The wider context of the discourse of tinji includes, in addition to the legacy of the war, memories of the Soviet Union and the enormous and difficult to measure effect of the labour migration of hundreds of thousands of Tajiks to Russia and elsewhere. ${ }^{50}$ In such circumstances, the approaches of conflict avoidance and accommodation can be broadly effective as strategies of 'peacebuilding'. Hence the prospects for the escalation of conflicts to a 'political' level where local authorities, organised crime or neighbouring regions become involved in mobilizing ethnic or patronage based groups are extremely low.

As demonstrated by the above analysis, there are profound differences in the practices of 'peace' found in present day Tajikistan and those of the discourse of peacebuilding which has an enormous influence on international aid allocation in Tajikistan. The discursive institutions of conflict accommodation and avoidance found in Tajikistan's villages are confronted with strategies of conflict transformation through the establishment of formally democratic systems of self-governance. ${ }^{51}$ Peacebuilding, as a theory of transition to democracy, implicitly and at times explicitly make claims to a 'natural' and universal applicability which is above or beyond ideology. However, my research suggests that peacebuilding represents a particular approach to peace which emerges from the westernised identity and neo-liberal norms of the international community. Peacebuilding may have an ideological quality among the international community, but as 'representation of the realities of Central Asia', its practices,

become what James C. Scott terms 'thin simplifications,' wherein the complexity of any lived situation is reduced to a finite set of terms, with limited possibilities. Complex and indeterminate series of relationships are hypostasised into a causal narrative, wherein factors that do not fit, do not make sense, or are not rhetorically desirable are dismissed in terms of a more easily identifiable concept, 'danger. ${ }^{52}$

Indeed in the case of Tajikistan there are numerous examples of actors within peacebuilding programmes stepping away from the rhetoric of their programme proposals in a pragmatic compromise with local institutions and ideas. ${ }^{53}$ This may be for the better. 
Scott has warned us that when the 'simplifications' of 'high modernism' ride roughshod over 'practical knowledge' of local actors both technical 'progress' and immense human suffering can result. ${ }^{54}$

\section{Conclusions: the complexities of 'peacebuilding'}

This article has not attempted to establish a causal link between a certain discourse and peace but rather to illustrate the correlation between the Tajik 'peace' and the existence of multiple interacting discourses of peace (as summarized in Table 3). In conclusion it now reflects on the implications for peacebuilding from the cautionary tale of Tajikistan.

Mirostroitelstvo and tinji, I argue, cannot simply be dismissed as superficial or illegitimate as they both reflect and reproduce identities which have a far greater purchase in Central Asian societies than that of peacebuilding. It is this very context which has determined the limits of the discourse of peacebuilding in Tajikistan, and why its practitioners, in adapting to local circumstances, have often failed to practice what they preach. Together the interaction of discourses means that post-conflict Tajikistan has not proceeded directly towards democracy, a new authoritarian order or an apolitical society. Although today it most clearly resembles authoritarian governance, it also represents a hybrid, internationalized political space which superficially contains elements of all three. Local and international actors constantly interpret events to reduce complex outcomes to accord with their discursive representations of 'peace'. Thus, practical forms of 'peacebuilding' are ones based on the ambiguities present when multiple discourses, emanating from differing contexts, are in debate. This debate is characterised not only by contentions between the 'public transcripts' demonstrated above, and simulated in internationally-sponsored dialogue activities. It also produces 'hidden transcripts' as actors adapt, resign to and subvert the practices and representations of others. ${ }^{55}$ Peacebuilding is, therefore, neither an objective process of democratization nor a purely subjective category that can be interpreted in any way by any given identity group. Rather, it is a complex and 'intersubjective' process of change entailing the legitimation of new relationships of power. This is the key theoretical conclusion of this essay. 
[TABLE 3 ABOUT HERE]

Table 3. Summary Table of Discourses of 'Peace' in Tajikistan

\begin{tabular}{|c|c|c|c|}
\hline Discourse & $\begin{array}{l}\text { Spatial and } \\
\text { Identity } \\
\text { bases }\end{array}$ & Discursive strategies & Overall Approach \\
\hline Peacebuilding & $\begin{array}{l}\text { The } \\
\text { 'International } \\
\text { Community' }\end{array}$ & $\begin{array}{l}\text { - Democratisation } \\
\text { - Governance/State- } \\
\text { building } \\
\text { - Civil society }\end{array}$ & Conflict Transformation \\
\hline $\begin{array}{l}\text { Mirostroitelstvo } \\
\text { (Russian: } \\
\text { peacebuilding) }\end{array}$ & $\begin{array}{l}\text { National and } \\
\text { regional elites }\end{array}$ & $\begin{array}{l}\text { - Avtoritet (authority) } \\
\text { - Stabilnost (stability) }\end{array}$ & Peace Enforcement \\
\hline $\begin{array}{l}\text { Tinji } \\
\text { (Tajik: peacefulness/ } \\
\text { wellness) }\end{array}$ & $\begin{array}{l}\text { Local } \\
\text { communities }\end{array}$ & $\begin{array}{l}\text { - Denial of conflict } \\
\text { - Unity/cohesion } \\
\text { - Anti-politics }\end{array}$ & $\begin{array}{l}\text { Conflict Avoidance and } \\
\text { Accommodation }\end{array}$ \\
\hline
\end{tabular}

Tajikistan's widely-acknowledged success in achieving an end to violence is a product of this ambiguity: in terms of peacebuilding it is 'democratic' enough to remain the recipient of relatively significant donor assistance and international support; in terms of mirostroitelstvo it is 'stable' enough for the government's authority to be accepted as unquestionable and unchallengeable by its potential political rivals, and accepted on the international stage by its neighbours; in terms of tinji it is 'harmonious' enough for conflict to be avoided and accommodated, and political participation shunned, by millions of ordinary Tajiks. Tajikistan's political party system provides a good example. The existence of six legally-registered and nominally functioning political parties is sufficient progress in terms of 'democracy' to please the international community. However, the fact that one of these parties operates as an umbrella for the solidarity group of the man who has been in charge of Tajikistan for thirteen years is evidence of the government's 'authority' and 'stability' to domestic and regional neighbours. Finally, the near irrelevance of party politics to the everyday lives of ordinary Tajiks allows them 
to accept the system as one which maintains 'harmony' and does not unnecessarily disturb their informal economies and social life. It is this ambiguity of 'peace' which characterises the Tajik peace. $^{56}$

It may, to speak counterfactually, never have been possible to create a vibrant party system, fair elections, decentralized government, or a reformed security sector over the course of several years or even decades of peacebuilding in Tajikistan. Such change, when it occurs, more likely reflects processes of broader political and economic change, made meaningful by local discourses. They are neither inevitable nor irreversible. However, strategic interventions by informed and reflexive international actors - of which, sadly, there are precious few - may achieve small movements. But interpreting such changes as steps on the road to democratization is perhaps more a reflection on the ideological predilections of the author than a credible work of analysis. Strategic interventions in the aftermath of war should be valued in and of themselves for reducing the probability of violence. Most importantly they must be enacted with the understanding that they are contingent on both the wider context and future events without trying to interpret their significance through a grand narrative (such as peacebuilding or mirostroitelstvo) which transcends both cultural differences and individual agency. Such interventions are necessarily tentative and ambiguous - in that they are open to contrasting interpretations and enactments.

Understanding the multiplicity of discourses in play and their cultural contexts leads to a richer understanding of 'peacebuilding'. It is not that the existence of multiple discourses represents a problem of contradiction, but rather that this ambiguity and intertextuality is an essential quality of the concept in practice. The case of Tajikistan illustrates that effective peacebuilding interventions must be ones grounded in contextual particularities and comfortable with ambiguities. Grand narratives remain important only to the extent that they interact, are interpreted and subverted in context. As such, peacebuilding is essentially contested. 


\section{Acknowledgements}

I wish to thank Mark Hoffman, Stacy Closson and participants of LSE's Conflict, Peace and Security Workshop for comments on early drafts of this article. Helpful suggestions were also offered by participants of the World International Studies Convention, Istanbul, 24-27 August 2005, and the UNESCO conference, 'Human Security in Central Asia', Bishkek, Kyrgyzstan, 8-9 September 2005. Thanks also go to the anonymous peer reviewers for their insightful comments. The staff of Mercy Corps', who the author worked with during fieldwork, provided vital access, assistance and testimonies. However, the views contained herein, their reductions and imperfections are the sole work of the author.

\section{NOTES}

${ }^{1}$ The article continues to distinguish peacebuilding (the basic discourse of the international community) from 'peace' and 'peacebuilding' (the differentiated and contextualized practise of post-conflict change) with the use of inverted commas.

${ }^{2}$ This term comes from Lene Hansen, Security as Practice: Discourse Analysis and the Bosnian War, London: Routledge, 2006. The revision of this article was inspired in part by a reading of Hansen's book.

${ }^{3}$ James C. Scott, Seeing Like a State: How Certain Schemes to Improve the Human Condition Have Failed, New Haven: Yale University Press, 1998.

${ }^{4}$ See, for example, Michael Lund, 'What Kind of Peace is Being Built? Taking stock of Post-Conflict Peacebuilding and Charting Future Directions', a paper prepared for the International Development Research Centre (IDRC), Ottawa, January 2003; Sunham Bastian and Robin Luckham (eds), Can Democracy Be Designed? The Politics of Institutional Choice in Conflict-Torn Societies, London: Zed, 2003. The ongoing work on the peacebuilding commission also shows some interest in finer conceptual analysis.

${ }^{5}$ See, Hansen (n.2 above).

${ }^{6}$ Shirin Akiner, Tajikistan: Disintegration or Reconciliation? London: Royal Institute of International Affairs, 2001. 
${ }^{7}$ OSCE/ODIHR, Republic of Tajikistan Parliamentary Elections, 27 February and 13 March 2005, OSCE/ODIHR Election Observation Mission Final Report, Warsaw, 31 May 2005.

${ }^{8}$ International Crisis Group, 'Tajikistan's Politics: Confrontation or Consolidation?', Asia Briefing, 19 May 2004, p.19.

${ }^{9}$ Eva Bertram, 'Reinventing Governments: the promises and perils of United Nations peace building', Journal of Conflict Resolution, Vol.39, No.3, 1995, p.388.

${ }^{10}$ Roland Paris, 'International peacebuilding and the "mission civiliatrice",' Review of International Studies, Vol.28, No.4, 2002, pp.637-56.

${ }^{11}$ Roland Paris, 'Peacebuilding and the Limits of Liberal Internationalism', International Security, Vol.22, No.2, 1997, pp.54-89.

${ }^{12}$ Lund (n.4 above), p.22.

${ }^{13}$ See, for example, Airat R. Aklaev, Democratization and Ethnic Peace, Aldershot: Ashgate, 1999; Sunham Bastian and Robin Luckham (eds), Can Democracy Be Designed? The Politics of Institutional Choice in Conflict-Torn Societies, London: Zed, 2003; Tobias Debiel and Alex Klein (eds), Fragile Peace: State Failure, Violence, and Development in Crisis Regions, London: Zed, 2002.

${ }^{14}$ Boutros Boutros-Ghali, Report on the work of the organization from the forty-seventh to the forty-eight session of the general assembly, New York: United Nations, 1993, p.3.

${ }^{15}$ Human Security Report 2005: War and Peace in the $21^{\text {st }}$ Century, Oxford: Oxford University Press, 2005, p.9.

${ }^{16}$ UN Security Council, Press Release SC/6860 4141st Meeting (Night) 12 May 2000. (www.un.org/News/Press/docs/2000/20000512.sc6860.doc.html) Accessed: 22 May 2004.

17 'Tajikistan: Interview with UN Secretary-General's representative', 27 Nov 2002, IRIN (www.irinnews.org), accessed: 22 May 2004.

${ }^{18}$ It should be noted that on some areas, such as suppression of the media and electoral law, Hoagland has been critical of the government. See, 'US envoy calls for changes to 
Tajik laws on election, media', Asia-Plus news agency, Dushanbe, in Russian, 0830 gmt, 3 March 2004 (www.eurasianet.org/resource/tajikistan/hypermail/news/0021.shtml).

${ }^{19}$ See, for example: Kamoludin Abdullaev and Sabine Frezier, What Peace Five Years After The Signing of the Tajik Peace Agreement? Strategic Conflict Assessment and Peacebuilding Framework, a report for the UK Government Conflict Prevention Pool, December 2003; Catherine Barnes and Kamoludin Abdullaev (eds), 'The Politics of Compromise: The Tajikistan Peace Process', Accord: An International Review of Peace Initiatives, Conciliation Resources: No.10, 2001; Anna Matveeva, Central Asia: A Strategic Framework for Peacebuilding, London: International Alert, 2006; Harold H. Saunders and Randa Slim, 2001 'The Inter-Tajik Dialogue: from civil war towards civil society'; Harold H. Saunders, A Public Peace Process: Sustained Dialogue to Transform racial and Ethnic Conflict, New York: St Martin's, 1999.

${ }^{20}$ For a critical analysis of such interventions see, John Heathershaw, 'Peace as Complex Legitimacy: Politics, Space and Discourse in Tajikistan's Peacebuilding Process', unpublished $\mathrm{PhD}$ thesis, London School of Economics and Political Science, 2006.

${ }^{21}$ See, Zalmay Khalilzad, 'How to Nation-Build: ten lessons from Afghanistan', The National Interest, Summer 2005, No.80, pp.19-28; Charles Tripp, 'The United States and state-building in Iraq', Review of International Studies, Vol.30, 2004, pp.545-58.

${ }^{22}$ Simon Chesterman, 'Bush, the United Nations and Nation-building,' Survival, Vol.46, No.1, 2004, p.114.

${ }^{23}$ Najam Abbas, 'Dimensions and Dynamics of Tajikistan's Civil Society Discourse', paper at the $5^{\text {th }}$ CESS Annual Conference, Indiana University, Bloomington, 14-17 Oct. 2004, p.6.

${ }^{24}$ See John Heathershaw, Emil Juraev, Michael von Tangen-Page and Lada Zimina, 'Small Arms in Central Asia', Eurasia Studies Series, International Alert; 2004 (www.international-alert.org/pdf/pubsec/MISAC_eurasia_4.pdf ).

${ }^{25}$ Interview with Kathleen Samuels, International Crisis Group, Dushanbe, 10 June 2003.

${ }^{26}$ Akiner (n.5 above), p.58. 
${ }^{27}$ Morgan Y. Liu, 'Detours from Utopia on the Silk Road: Ethical Dilemmas of Neoliberal Triumphalism', Central Eurasian Studies Review, Vol.2, No.2, 2003, pp.2-10; Nick Megoran, 'Preventing conflict by building civil society: post-development theory and a Central Asian - UK policy success story', Central Asian Survey, Vol.24, No.1, March 2005, pp.83-96.

${ }^{28}$ Morgan Y. Liu (n.27 above), pp.3-4.

${ }^{29}$ Saodat Olimova and Anthony Bowyer, Political Parties in Tajikistan, Washington, International Foundation for Electoral Systems, November 2002, pp.3-4.

${ }^{30}$ John Schoeberlein, 'Regional Introduction: A Host of Preventable Conflicts' in Paul van Tongeren, Hans van de Veen and Juliette Verhoeven (eds), Searching for peace in Europe and Eurasia: an overview of conflict prevention and peacebuilding activities, Boulder, Co: Lynne Rienner, 2002, p.477.

${ }^{31}$ Akiner (n.5 above), p.88.

${ }^{32}$ See John Heathershaw, 'The Paradox of Peacebuilding: Peril, Promise and Small Arms in Tajikistan', in Central Asian Survey, Vol.24 No.1, March, 2005, pp.21-38.

${ }^{33}$ See Heathershaw, 'New Great Game or Same Old Ideas? Neo-sovietism and the International Politics of Imagining "Central Asia", in David Dusseault (ed.), The CIS: Form or Substance?, Helsinki: Kikimora, 2006, pp.00-00.

34 Trevor Waters, 'Russian peacekeeping in Moldova: source of stability or neoimperialist threat?', in John MacKinlay and Peter Cross (eds), Regional Peacekeepers: the paradox of Russian peacekeeping, Tokyo: United Nations University Press, 2003, p.150.

35 John MacKinlay and Evgenii Sharov, 'Russian peacekeeping operations in Georgia', in MacKinlay and Cross (eds), ibid., pp.63-110.

36 Ibid.

${ }^{37}$ Smith-Serrano, 'CIS peacekeeping in Tajikistan', in MacKinlay and Cross (eds), ibid., p.181.

${ }^{38}$ Dov Lynch, Peacekeeping Strategies towards the CIS, London: RIIA,1999.

${ }^{39}$ See Heathershaw (n.33 above), 2006. 
${ }^{40}$ Interview with Abduhalim Gaffurov, Chairman of the official Socialist Party of Tajikistan, Dushanbe, 5 Aug. 2005.

${ }^{41}$ Interview with Muso Asozoda, Head of Administration, People's Democratic Party of Tajikistan, Dushanbe, 17 Aug. 2005.

${ }^{42}$ See Hansen (n.2 above).

43 The research was initially conducted for a baseline analysis of Mercy Corps' Peaceful Communities Initiative (PCI) in Tajikistan. The five communities selected for study were Navbuned and Tojikokjar (both in Asht district), along with Koshonar, Margedar and Novabad (all in Panjakent district).

${ }^{44}$ When asked to assess whether the livelihood of the village had improved over the last year, an overall majority felt it had. However, the minority who answered 'no' was composed of just one man but half of all women (15 out of 30), giving the impression that the threats identified above rendered a greater impact on women than men. Moreover, it may indicate that, excluded from elite networks, women are more ready to communicate in 'hidden transcripts' and dissent from the community leadership.

${ }^{45}$ Christine Bichsel, 'In search of harmony: repairing infrastructure and social relations in the Ferghana Valley', Central Asian Survey, Vol.24, No.1, March, 2005, pp.53-66.

${ }^{46}$ Sometimes the term mahallinski commitet (community committee) is used to denote the leadership of the community, at other times simply raisi mahalla or raisi kishlok (head of the community or head of the village).

${ }^{47}$ Ironically this was the one CIG focus group we conducted where women actually spoke up. As noted in $\mathrm{n} .41$ above, such activity may serve to conceal hidden transcripts of social dissent. See James C. Scott, Domination and the Arts of Resistance: Hidden Transcripts, New Haven: Yale, 1990.

${ }^{48}$ I later discovered that the three political parties represented in the village are the President's own National Democratic Party of Tajikistan, as well as the Communist Party of Tajikistan and the Socialist Party of Tajikistan - neither of which are effectively oppositional.

${ }^{49}$ Scott (n.3 above), p.319. 
${ }^{50}$ There are estimates of 500,000-1,000,000 Tajiks away on labour migration at any one time. This is most common in the Rasht valley which suffered longest during the war. In 2005, I found 20-25 per cent of the population of villages where I was conducting fieldwork away on labour migration. In the village of Kadara for example, an estimated 70 per cent of families had at least one member in Russia, providing an estimated 50 per cent of their family incomes.

${ }^{51}$ This is openly acknowledged by another Mercy Corps Programme working in Tajikistan, the Tajikistan Conflict Prevention Program (TCCP) in Tavildera. The programme uses the Thomas-Kilman conflict model to interpret Tajiki conflict avoidance and accommodation strategies and introduce modes of collaborative conflict transformation. Interview with Barbara Stuart, TCCP Chief of Party, Tavildera, 26 July, 2005.

${ }^{52}$ Chad Thompson and John Heathershaw, 'Introduction: Discourses of Danger in Central Asia', Central Asian Survey, special issue, Vol.24, No.1, March, 2005, pp.1-4.

${ }^{53}$ See Heathershaw (n.32 above).

${ }^{54}$ Scott (n.3 above), 1998.

${ }^{55}$ Scott (n.47 above), 1990.

${ }^{56}$ For a much more substantive elaboration of this argument see Heathershaw (n.20 above). 